\title{
Penerapan model pembelajaran reciprocal teaching ditinjau dari kemampuan penalaran matematis peserta didik pada materi bangun datar segiempat
}

\author{
Trini Andira *, Budi Santoso, Muhammad Yusup \\ Program Studi Pendidikan Matematika, Universitas Sriwijaya. Jalan Raya Palembang-Prabumulih \\ Indralaya Ogan Ilir 30662, Sumatera Selatan, Indonesia. \\ * Corresponding Author. E-mail: trini.andira@yahoo.com
}

Received: 24 October 2017; Revised: 29 December 2017; Accepted: 17 September 2018

\begin{abstract}
Abstrak
Penalaran matematis merupakan salah satu aspek penting yang sangat dibutuhkan peserta didik dalam mempelajari matematika. Berbagai upaya telah dilakukan untuk meningkatkan kemampuan penalaran matematis peserta didik, salah satunya dengan penerapan model pembelajaran Reciprocal Teaching. Penelitian ini merupakan penelitian deskriptif kuantitatif yang bertujuan untuk mengetahui proses pembelajaran dan kemampuan penalaran matematis peserta didik melalui penerapan model pembelajaran Reciprocal Teaching pada materi bangun datar segiempat di kelas VII. Subjek penelitian ini adalah 34 peserta didik kelas VII.5 yang berasal dari SMP Negeri 13 Palembang. Data dikumpulkan menggunakan observasi dan tes. Data yang diperoleh dalam penelitian ini adalah data hasil observasi kegiatan peserta didik pada saat diterapkan model pembelajaran Reciprocal Teaching dan data hasil tes untuk melihat kemampuan penalaran matematis peserta didik setelah diterapkan model pembelajaran Reciprocal Teaching. Analisis data dilakukan secara deskriptif kuantitatif. Hasil penelitian menunjukkan bahwa (1) keaktifan peserta didik selama diterapkan model pembelajaran Reciprocal Teaching berada pada kategori "sangat aktif" dengan persentase rata-rata $88,71 \%$; (2) kemampuan penalaran matematis peserta didik setelah diterapkan model pembelajaran Reciprocal Teaching berada pada kategori "cukup" dengan rata-rata skor sebesar 67,89.
\end{abstract}

Kata Kunci: pembelajaran reciprocal teaching, penalaran matematis, pembelajaran matematika

\section{Applying of reciprocal teaching learning model viewed from students' mathematical reasoning on quadrilateral matter}

\begin{abstract}
The mathematical reasoning was one of the important aspects that students need in learning mathematics. Various efforts have been made to improve students' mathematical reasoning skills, one of which was the application of the Reciprocal Teaching learning model. This research was a quantitative descriptive research that aims to explain the process of learning implementation and student's mathematical reasoning ability by using the Reciprocal Teaching learning model on the quadrilateral matter in class VII. The subjects of this research were 34 students of class VII.5 from SMP (Junior High School) Negeri 13 Palembang, South Sumatera, Indonesia. Data were collected using observations and tests. The data obtained in this research were the observation data of students activities when applied the Reciprocal Teaching learning model and the test results data to see students' mathematical reasoning abilities after applying the Reciprocal Teaching learning model. The results of research showed that (1) student activity during applying the Reciprocal Teaching learning model was in the "very active" category with an average percentage of $88.71 \%$; (2) students' mathematical reasoning abilities after applying the Reciprocal Teaching learning model was in the "enough" category with an average score of 67.89 .
\end{abstract}

Keywords: reciprocal teaching learnig, mathematical reasoning ability, learning of mathematics

How to Cite: Andira, T., Santoso, B., \& Yusup, M. (2018). Penerapan model pembelajaran reciprocal teaching ditinjau dari kemampuan penalaran matematis peserta didik pada materi bangun datar segiempat. Pythagoras: Jurnal Pendidikan Matematika, 13(1), 88-98. doi:http://dx.doi.org/10.21831/pg.v13i1.16579

do

http://dx.doi.org/10.21831/pg.v13i1.16579 


\section{PENDAHULUAN}

Dewasa ini, pendidikan tidak lagi dipandang sebagai aktivitas transfer pengetahuan dari guru ke peserta didik. Lebih dari itu, pendidikan juga harus mampu memfasilitasi peserta didik untuk mengembangkan kemampuan berpikirnya. Pada Permendikbud No. 58 Tahun 2014 tentang landasan psikopedagogis untuk jenjang pendidikan menengah khususnya SMP dijelaskan implementasi pendidikan yang selama ini lebih menekankan pada pengetahuan, perlu dikembangkan menjadi kurikulum yang menekankan pada proses pembangunan sikap, pengetahuan, keterampilan peserta didik melalui berbagai pendekatan yang mencerdaskan dan mendidik. Hal ini sesuai dengan pendapat Nurhayati (2012), bahwa dalam pembelajaran matematika dibutuhkan kemampuan guru untuk mendesain pembelajaran menggunakan pendekatan atau metode yang dapat mencerdaskan peserta didik, menjadikan peserta didik sebagai subjek, sehingga efek dari pembelajaran matematika tersebut akan menjadikan peserta didik memiliki kemampuan memahami konsep, kemampuan komunikasi, kemampuan pemecahan masalah, dan kemampuan penalaran. Hal tersebut tentunya juga sejalan dengan standar isi Kurikulum 2013 yang menekankan bahwa kemampuan penalaran merupakan salah satu kompetensi yang harus dimiliki peserta didik pada pembelajaran matematika.

Penalaran sangatlah penting dalam kehidupan sehari-hari karena berguna untuk membantu menyelesaikan masalah-masalah yang terjadi (Rahman, 2014; Sulistyowati \& Sugiman, 2014; Widiastuti \& Santosa, 2014; Falach, 2016). Salah satunya dapat memecahkan permasalahan matematika, menyajikan pernyataan matematika, dan kemudian menarik kesimpulan dari pernyataan. Kemampuan untuk bernalar menjadikan peserta didik dapat memecahkan masalah dalam kehidupannya, di dalam dan di luar sekolah (Andalusia, 2011). Kemampuan penalaran juga merupakan salah satu komponen proses standar dalam Principles and Standards for School Mathematics selain kemampuan pemecahan masalah, representasi, komunikasi, dan koneksi (NCTM, 2000). Berdasarkan laporan penelitian Andalusia (2011) menyarankan agar guru banyak memberikan kesempatan kepada peserta didik untuk dapat menggunakan penalaran induktif mereka dalam pola-pola dan membentuk dugaan untuk meningkatkan kemampuan penalaran yang efektif. Penalaran matematis merupakan suatu proses berpikir yang dilakukan dengan cara menarik kesimpulan yang bersifat umum dari kasus-kasus yang bersifat individual atau disebut dengan penalaran induktif (Annisah, Zulkardi, \& Darmawijoyo, 2011).

Menurut Sardiyanti (2010), lemahnya pemahaman peserta didik pada umumnya dilatar belakangi oleh pengajaran matematika yang menuntut peserta didik menunjukkan sikap yang aktif, kreatif, inovatif dan bertanggung jawab. Tetapi kenyataannya, tujuan pembelajaran matematika belum tercapai secara optimal dikarenakan seringkali peserta didik kurang merespon terhadap pelajaran matematika, peserta didik tidak fokus mengikuti pembelajaran, sebagian peserta didik berbincang dengan peserta didik lainnya ketika guru menyampaikan materi, kurangnya kemampuan bertanya dikarenakan rasa ingin tahu terhadap pembelajaran matematika masih rendah, tugas dan PR selalu tidak dikerjakan dan sebagian kecil peserta didik yang mampu menyelesaikan soal-soal matematika. Dalam bekerja kelompok banyak dari anggota kelompok yang hanya mencantumkan nama saja tanpa ikut berpartisipasi dalam kelompok. Tanggung jawab peserta didik rendah, baik terhadap dirinya sendiri maupun terhadap kelompok. Hal tersebut dapat disebabkan karena pembelajaran matematika kurang bermakna.

Kurang bermaknanya pembelajaran matematika menimbulkan kurangnya keaktifan peserta didik dalam proses pembelajaran, sehingga ketika guru memberikan suatu permasalahan matematika kepada peserta didik, sebagian peserta didik hanya menunggu solusi-solusi permasalahan yang akan disampaikan oleh guru tanpa berfikir untuk mencari solusi sendiri (Rahman, 2015). Selain itu, peserta didik sering mengalami kesulitan dalam belajar materi segiempat. Hal ini terlihat dari hasil persentase penguasaan materi soal matematika pada Ujian Nasional tahun 2014/ 2015 peserta didik SMP menunjukkan bahwa tingkat kemampuan peserta didik dalam menguasai materi geometri yang paling rendah yaitu sebesar $51,84 \%$. Rendahnya hasil ujian tersebut terbukti bahwa peserta didik menagalami permasalahan dalam menyelesaikan soal geometri. Hal ini dibuktikan dengan hasil ulangan pokok bahasan segiempat diperoleh rata-rata nilai 55 dan ketuntasan belajar 50\% dari standar KKM. Dengan menggunakan standar tersebut banyak peserta didik memperoleh nilai dibawah KKM, artinya banyak peserta didik belum tuntas dan belum mencapai ketuntasan belajar. Masalah ini merupakan suatu tantangan bagi tenaga pendidik karena itu, tenaga pendidik harus lebih berpikir 
dan bertindak kreatif dalam mengefektifkan pembelajarannya. Salah satunya adalah dengan menerapkan model pembelajaran yang tidak membosankan dan dapat meningkatkan semangat belajar peserta didik.

Berdasarkan latar belakang diatas yang sudah dijelaskan, maka salah satu model pembelajaran yang tidak membosankan dan dapat meningkatkan belajar peserta didik yaitu dengan menerapkan model pembelajaran Reciprocal Teaching. Hal ini dikarenakan Reciprocal Teaching merupakan salah satu model pembelajaran yang diduga kuat bisa meningkatkan kemampuan penalaran matematis peserta didik. Dugaan ini sejalan dengan yang dinyatakan oleh Palinscar dan Brown (1984) bahwa reciprocal teaching dapat meningkatkan kemampuan penalaran peserta didik. Kemudian Firdaus, Darma, dan Haryadi (2014) juga menyatakan bahwa kemampuan penalaran matematis pada mahapeserta didik dalam pembelajaran model Reciprocal Teaching lebih baik dibandingkan pembelajaran konvensional.

Menurut Angela (2013), Reciprocal Teaching adalah salah satu model pendekatan pembelajaran dimana peserta didik dilatih untuk memahami suatu naskah dan memberikan penjelasan pada teman sebaya dalam kelompoknya. Menurut Suparni (2016) menyatakan bahwa pengajaran Reciprocal Teaching ini menjadikan peserta didik lebih aktif dan kreatif dalam menemukan gagasan baru dalam menyelesaikan permasalahan matematika melalui kegiatan belajar mengajar. Model Pembelajaran Reciprocal Teaching yang mengajarkan kepada peserta didik tentang empat strategi kognitif yang dilakukan peserta didik secara berkelompok agar peserta didik dapat memahami suatu materi pelajaran dengan baik (Putri, 2011). Keempat strategi tersebut dijelaskan oleh Palinscar (1986) meliputi membaca bahan ajar yang disediakan, merangkum bahan ajar yang dianggap penting, membuat pertanyaan, memprediksi, dan mengklarifikasi. Hal ini sesuai dengan pendekatan saintifik yang terdapat pada proses pembelajarannya yaitu mengamati, menanya, mengumpulkan informasi/ mencoba, menalar, dan mengomunikasikan (Permendikbud, 2014).

Pada tahap summarizing peserta didik diarahkan untuk mencatat bahan ajar. Menurut Syah (1994) mencatat materi pelajaran bertujuan untuk meningkatkan daya ingat, sehingga konsep dapat dipahami dengan baik. Pada tahap questioning digunakan untuk memonitor dan menge- valuasi sejauh mana pemahaman pembaca terhadap bahan bacaan. Pembaca dalam hal ini adalah peserta didik mengajukan pertanyaanpertanyaan berhubungan dengan konsep yang kurang dipahami dan diajukan kepada kelompok yang tampil. Pada tahap predicting peserta didik melakukan perkiraan mengenai konsep apa yang akan didiskusikan. Selanjutnya, tahap clarifying bertujuan untuk melengkapi, mengklarifikasi, dan memodifikasi konsep yang baru saja didapat kemudian peserta didik diminta untuk mempresentasikan hasil diskusi di depan kelas dan peserta didik lain diberikan kesempatan untuk mengajukan pertanyaan/mengajukan tanggapan. Dalam pembelajaran peserta didik berperan seakan-akan menjadi guru menggantikan peran guru untuk mengajar teman-teman dalam kelompoknya, sedangkan guru berperan sebagai fasilitator yang memberi kemudahan, dan pembimbing yang melakukan pembelajaran secara mandiri (Kawedar, 2013).

Berdasarkan latar belakang permasalahan dan kajian teori yang telah dikemukakan sebelumnya, maka penelitian ini bertujuan untuk mengetahui proses pembelajaran dan kemampuan penalaran matematis peserta didik melalui penerapan model pembelajaran Reciprocal Teaching pada materi bangun datar segiempat di kelas VII. Dari hasil penelitian ini diharapkan dapat diperoleh informasi mengenai best practice terkait penerapan model pembelajaran Reciprocal Teaching untuk meningkatkan kemampuan penalaran matematis siswa.

\section{METODE}

Penelitian ini merupakan penelitian deskriptif kuantitatif yaitu penelitian yang bertujuan untuk mendeskripsikan atau menggambarkan suatu keadaan dengan menggunakan alat ukur tertentu, yaitu dengan menggunakan lembar observasi untuk mengetahui gambaran bagaimana penerapan model pembelajaran Reciprocal Teaching dan menggunakan hasil tes untuk mengetahui kemampuan penalaran matematis peserta didik setelah diterapkan pembelajaran Reciprocal Teaching. Variabel dalam penelitian ini adalah kemampuan penalaran matematis peserta didik setelah diterapkan model pembelajaran Reciprocal Teaching. Penelitian dilakukan selama 3 kali pertemuan di kelas VII.5 SMP Negeri 13 Palembang semester genap tahun ajaran 2016/2017 yang terdiri dari 34 peserta didik. 
Teknik pengumpulan data yang digunakan adalah observasi dan tes. Observasi dalam penelitian ini dilakukan dengan tujuan untuk melihat kegiatan peserta didik dalam penerapan proses pembelajaran menggunakan model pembelajaran Reciprocal Teaching. Observasi dilakukan selama proses pembelajaran berlangsung, yaitu sejak awal kegiantan sampai guru menutup pelajaran. Observasi untuk melihat kegiatan peserta didik dalam penerapan proses pembelajaran menggunakan model pembelajaran Reciprocal Teaching ini dilakukan secara langsung oleh 4 orang observer dengan menggunakan lembar observasi yang memuat indikator kegiatan peserta didik pada model pembelajaran Reciprocal Teaching. Saat dikelas satu orang observer merekam aktivitas yang terjadi selama pembelajaran menggunakan handycame, sedangkan 3 observer lain mengisi lembar obsrvasi dengan mengamati kegiatan masing-masing peserta didik.

Dalam menganalisis lembar observasi, langkah-langkah yang harus dilakukan observer meliputi: (1) penilaian lembar observasi aktivitas peserta didik dilakukan dengan cara memberi skor untuk tiap deskriptor yang muncul, skor 0 jika deskriptor tidak muncul dan skor 1 jika deskriptor muncul; (2) rumus untuk menentukan presentase aktivitas peserta didik untuk setiap pertemuan adalah:

$$
\text { Presentase aktivitas siswa }=\frac{\text { aspek yang muncul }}{\text { jumlah skor maksimal }} \times 100 \%
$$

Hasil observasi (dalam \%) dapat dikonversikan ke dalam data kualitatif untuk menentukan kategori keaktifan peserta didik selama proses pembelajaran seperti yang terlihat pada Tabel 1.

Tabel 1. Persentase Keterlaksanaan Model Pembelajaran

\begin{tabular}{cc}
\hline Skor (\%) & Kategori \\
\hline $81-100$ & Sangat Aktif \\
$61-80$ & Aktif \\
$41-60$ & Cukup Aktif \\
$21-40$ & Kurang Aktif \\
$0-20$ & Tidak Aktif \\
\hline
\end{tabular}

Tes digunakan untuk mengukur tingkat kemampuan penalaran peserta didik setelah diterapkan model pembelajaran Reciprocal Teaching terhadap materi bangun datar segiempat yang dilaksanakan. Tes diberikan setelah 2 kali pertemuan pembelajaran. Bentuk tes yang digunakan adalah tes subjektif berbentuk esai (uraian) dilakukan selama 70 menit. Soal disesuaikan dengan indikator-indikator kemampuan penalaran matematis. Sebelum digunakan, soal-soal tes divalidasi oleh pakar. Selanjutnya, untuk mendapatkan nilai tes akhir dilakukan dengan cara menjumlahkan skor dari semua jawaban peserta didik, lalu skor tersebut dikonversikan menjadi nilai dalam rentang 0-100, dengan rumus:

Nilai siswa $=\frac{\text { Jumlah skor yang diperoleh }}{\text { Jumlah skor maksimal }} \times 100$,

Pemberian nilai ditentukan dengan menggunakana kriteria penilaian seperti pada Tabel 2.

Tabel 2. Kriteria Nilai Kemampuan Penalaran Matematis

\begin{tabular}{cc}
\hline Nilai & Kategori \\
\hline $89 \leq \mathrm{n}<100$ & Sangat Baik \\
$77 \leq \mathrm{n}<89$ & Baik \\
$65 \leq \mathrm{n}<77$ & Cukup \\
$0 \leq \mathrm{n}<65$ & Kurang \\
\hline
\end{tabular}

(Permendikbud No. 53 Tahun 2015)

\section{HASIL DAN PEMBAHASAN}

\section{Hasil}

Penelitian ini dilaksanakan di SMP Negeri 13 Palembang. Penelitian ini berlangsung selama 3 kali pertemuan dengan 2 kali proses pembelajaran dan 1 kali tes. Proses pembelajaran dilakukan berdasarkan RPP yang telah dibuat sesuai dengan model pembelajaran Reciprocal Teaching. Pada pertemuan pertama dan kedua peneliti membagikan LKS yang telah dibuat. Proses pembelajaran menggunakan LKS yang dibuat untuk memunculkan 4 strategi-strategi model pembelajaran Reciprocal Teaching dengan 4 indikator yang mencakup 7 deskriptor. LKS dikerjakan secara berkelompok yang terdiri dari 5-6 peserta didik dalam masing-masing kelompok. LKS yang dibagikan memuat masalah kehidupan sehari-hari. Langkah-langkah pembelajaran yang menerapkan model pembelajaran Reciprocal Teaching yang dilakukan setiap pertemuan pada dasarnya sama, yang berbeda adalah pada materi pembelajaran dan permasalahannya.

Pertemuan pertama pembelajaran diawali dengan salam oleh guru dan mengabsen peserta didik, menanyakan kepada peserta didik tentang materi yang akan dipelajari bertujuan untuk melihat kesiapan peserta didik untuk belajar, menanyakan bentuk-bentuk yang terdapat dalam segiempat. Kemudian guru memberi motivasi kepada peserta didik bahwa materi persegi dan persegipanjang sangat penting, karena sangat diperlukan dalam kehidupan sehari-hari. Guru 
melakukan tanya jawab menanyakan bendabenda yang permukaannya berbentuk persegi dan persegi panjang. Kegiatan tersebut dilakukan untuk memancing pengetahuan peserta didik dalam kehidupan sehari-hari. Saat proses pembelajaran berlangsung digunakan tahapan model pembelajaran Reciprocal Teaching.

Pada tahap pertama, yaitu membuat rangkuman (Summarizing), guru membagikan LKS kepada setiap kelompok dan secara bersamaan peserta didik membaca teks bacaan yang terdapat pada LKS. Kemudian peserta didik menuliskan topik-topik yang penting dalam teks bacaan tersebut. Dalam menuliskan topik-topik tersebut peserta didik bukan hanya sekedar menulis melainkan mereka dapat mengingat untuk melaksanakan tahap selanjutnya. Tahap kedua yaitu membuat pertanyaan (Questioning), setelah menuliskan topik-topik penting dalam teks bacaan, peserta didik membuat pertanyaan dari teks bacaan yang akan diajukan pada tahap Clarifying dan peneliti membimbing kelompok peserta didik saat membuat pertanyaan. Tahap ketiga, yaitu memprediksi masalah (Predicting), dimana setelah membuat pertanyaan, peserta didik memprediksi jawaban dari permasalahan yang terdapat pada teks bacaan. Permasalahan tersebut berkaitan dengan persegi dan persegi panjang. Sebelumnya guru memberikan contoh permasalahan dalam kehidupan sehari-hari, kemudian guru memberikan permasalahan lain dalam bentuk soal cerita, yaitu permasalahan berupa sawah dibelakang rumah Ristan yang terbagi menjadi dua area berbentuk persegi dan persegipanjang. Area pertama berbentuk persegi seluas $625 \mathrm{~m}^{2}$. Kemudian area kedua berbentuk persegi panjang dengan ukuran panjang $50 \mathrm{~m}$ dan luasnya $\frac{1}{5}$ luas area pertama. Peserta didik memahami permasalahan yang ada dan menjawab di kolom predicting ini.

Tahap terakhir yaitu mengklarifikasi ( $\mathrm{Cla}$ rifying), dimana pada tahap ini, peserta didik mengklarifikasi jawaban. Dua orang peserta didik yang dipilih secara acak dari salah satu kelompok untuk mempresentasikan hasil diskusi yang telah mereka dapat. Dua orang anggota dari kelompok 7 yang dipilih oleh guru untuk mempresentasikan hasil diskusi kelompoknya. Sebelum dua orang anggota kelompok 7 mempresentasikan jawabannya, ternyata salah satu anggota dari kelompok 6 ada yang mengajukan pertanyaan kepada kelompok 7. Pertanyaan ini telah dibuat oleh kelompok 6 dari tahap sebe- lumnya yaitu tahap Questioning. Kemudian setelah dijawab, kelompok 7 langsung mempresentasikan hasil diskusinya didepan kelas. Guru memberikan penguatan terhadap hasil kerja kelompok peserta didik. Pada kegiatan ini, peserta didik mulai memberanikan diri untuk mengembangkan kemampuan bertanya dan mempresentasikan hasil diskusi didepan kelas. Guru bersama-sama dengan peserta didik melakukan refleksi dari kegiatan pembelajaran yang telah dilakukan. Selanjutnya, guru menginformasikan kegiatan untuk pertemuan selanjutnya yaitu jajar genjang dan belah ketupat.

Pertemuan kedua, pembelajaran diawali dengan salam oleh guru dan mengabsen peserta didik, menanyakan kepada peserta didik tentang materi yang akan dipelajari bertujuan untuk melihat kesiapan peserta didik untuk belajar. Kemudian guru memberi motivasi kepada peserta didik bahwa materi jajargenjang dan belahketupat sangat penting, karena sangat diperlukan dalam kehidupan sehari-hari. Guru melakukan tanya jawab menanyakan benda-benda yang permukaannya berbentuk jajar genjang dan belah ketupat. Kegiatan tersebut dilakukan untuk memancing pengetahuan peserta didik dalam kehidupan sehari-hari. Guru membagikan LKS kepada peserta didik tetapi sebelum membagi LKS kepada peserta didik, peneliti menjelaskan terlebih dahulu langkah-langkah dalam mengerjakan LKS sesuai dengan perintah yang ada pada LKS. Sementara peserta didik memperhatikan dan bertanya jika ada yang belum dimengerti.

Adapun tahapan pembelajaran pada pertemuan kedua diuraikan sebagai berikut. Pada tahap pertama, yaitu membuat rangkuman (Summarizing), peserta didik membaca teks bacaan yang terdapat pada LKS dan peserta didik menuliskan topik-topik penting yang ada pada LKS tersebut. Kemudian peserta didik menuliskan topik-topik yang penting dalam teks bacaan tersebut. Dalam menuliskan topik-topik tersebut, peserta didik bukan hanya sekedar menulis melainkan mereka dapat mengingat untuk melaksanakan tahap selanjutnya.

Pada tahap kedua, yaitu membuat pertanyaan (Questioning), setelah menuliskan topiktopik penting dalam teks bacaan, peserta didik membuat pertanyaan dari teks bacaan yang akan diajukan pada tahap Clarifying dan guru membimbing kelompok peserta didik saat membuat pertanyaan. Sedangkan pada tahap ketiga, yaitu memprediksi masalah (Predicting), setelah membuat pertanyaan, peserta didik memprediksi jawaban dari permasalahan yang terdapat pada teks 
bacaan. Permasalahan tersebut berkaitan dengan jajar genjang dan belah ketupat. Sebelumnya, guru memberikan contoh permasalahan dalam kehidupan sehari-hari, kemudian guru memberikan dua permasalahan dalam bentuk soal cerita, permasalahan pertama yaitu permasalahan berupa tanah berbentuk jajar genjang dengan ukuran alasnya $20 \mathrm{~m}$ dan tingginya $10 \mathrm{~m}$. Tanah tersebut akan ditanami rumput jepang sehingga permukaannya tertutupi rumput jepang. Jika biaya penanaman rumput tiap $1 \mathrm{~m}^{2}$ adalah $\mathrm{Rp7.500,-.}$ Berapa biaya penanaman rumput seluruhnya?. Permasalahan kedua yaitu terdapat hiasan dinding yang berbentuk belah ketupat dengan ukuran diagonal $22 \mathrm{~cm}$ dan $18 \mathrm{~cm}$. Berapakah luas hiasan dinding tersebut? Peserta didik memahami permasalahan yang ada dan menjawab di kolom predicting.

Tahap terakhir yang dilakukan yaitu mengklarifikasi (Clarifying), dimana pada tahap ini, peserta didik mengklarifikasi jawaban. Dua orang peserta didik yang dipilih secara acak dari salah satu kelompok untuk mempresentasikan hasil diskusi yang telah mereka dapat. Dua orang anggota dari kelompok 4 yang dipilih peneliti untuk mempresentasikan hasil diskusi kelompoknya. Sebelum dua orang anggota kelompok 4 mempresentasikan jawabannya, ternyata salah satu anggota dari kelompok 2 ada yang mengajukan pertanyaan kepada kelompok 4. Pertanyaan ini telah dibuat oleh kelompok 2 dari tahap sebelumnya yaitu tahap Questioning. Kemudian setelah dijawab, kelompok 4 langsung mempresentasikan hasil diskusinya didepan kelas. Peneliti memberikan penguatan terhadap hasil kerja kelompok peserta didik. Pada kegiatan ini, peserta didik mulai memberanikan diri untuk mengembangkan kemampuan bertanya dan mempresentasikan hasil diskusi didepan kelas. Guru bersama-sama dengan peserta didik melakukan refleksi dari kegiatan pembelajaran yang telah dilakukan. Selanjutnya, guru mengingatkan kembali kepada peserta didik untuk tetap semangat belajar dan menyampaikan bahwa pada pertemuan selanjutnya akan diadakan tes mengenai persegi, persegi panjang, jajar genjang, dan belah ketupat.

Berikut secara rinci rekapitulasi hasil observasi kegiatan peserta didik berdasarkan indikator-indikator model Pembelajaran Reciprocal Teaching dapat dilihat dalam Tabel 3.

Dari Tabel 3 dapat terlihat bahwa nilai rerata aktivitas pembelajaran selama 2 kali pertemuan sebesar 88,71 dengan kategori sangat aktif.
Hal ini berarti proses pembelajaran yang menerapkan model pembelajaran Reciprocal Teaching pada materi bangun datar segiempat dikelas VII sudah diterapkan dengan baik. Adapun rekapitulasi data hasil observasi kegiatan untuk masingmasing peserta didik dapat dilihat Tabel 4.

Tabel 3. Rekapitulasi Keterlaksanaan Model Pembelajaran Reciprocal Teaching

\begin{tabular}{|c|c|c|c|c|}
\hline \multirow{2}{*}{ Indikator } & \multicolumn{2}{|c|}{ Pertemuan } & \multirow{2}{*}{ Rerata } & \multirow{2}{*}{ Kategori } \\
\hline & 1 & 2 & & \\
\hline Summarizing & 100 & 100 & 100 & $\begin{array}{c}\text { Sangat } \\
\text { Aktif }\end{array}$ \\
\hline $\begin{array}{l}\text { Question } \\
\text { Generating }\end{array}$ & 67,65 & 70,59 & 69,12 & Aktif \\
\hline Predicting & 100 & 100 & 100 & $\begin{array}{c}\text { Sangat } \\
\text { Aktif }\end{array}$ \\
\hline Clarifying & 71,43 & 100 & 85,71 & $\begin{array}{c}\text { Sangat } \\
\text { Aktif }\end{array}$ \\
\hline \multicolumn{3}{|c|}{ Rata-rata } & 88,71 & $\begin{array}{c}\text { Sangat } \\
\text { Aktif }\end{array}$ \\
\hline
\end{tabular}

Tabel 4. Rekapitulasi Hasil Observasi Kegiatan Peserta didik Selama Pembelajaran

\begin{tabular}{cccc}
$\begin{array}{c}\text { Skor } \\
\text { Aktivitas }\end{array}$ & Frekuensi & $\begin{array}{c}\text { Persentase } \\
(\mathbf{\%})\end{array}$ & Kategori \\
\hline $81-100$ & 18 & 52,94 & Sangat Aktif \\
$61-80$ & 14 & 41,18 & Aktif \\
$41-60$ & 2 & 5,88 & Cukup Aktif \\
$21-40$ & 0 & 0 & $\begin{array}{c}\text { Kurang } \\
\text { Aktif } \\
\end{array}$ \\
$0-20$ & 0 & 0 & Tidak Aktif \\
\hline
\end{tabular}

Dari Tabel 3 dapat dilihat bahwa hasil observasi aktivitas keseluruhan peserta didik termasuk kategori sangat aktif yaitu dengan ratarata 88,71. Sedangkan, berdasarkan Tabel 4, peserta didik yang termasuk dalam kategori sangat aktif sebanyak 18 peserta didik atau $52,94 \%$. Peserta didik yang termasuk dalam kategori aktif sebanyak 14 peserta didik atau $41,18 \%$, dan peserta didik yang termasuk dalam kategori cukup aktif sebanyak 2 orang atau 5,88\%.

Peran aktif siswa dalam pembelajaran menggunakan model Reciprocal Teaching tidak terlepas dari karena adanya kegiatan-kegiatan yang secara pronsip mengharuskan siswa untuk mengkonstruk sendiri pengetahuannya. Beberapa hasil penelitian sebelumnya diantaranya Apino \& Retnawati (2017), Jailani, Sugiman, \& Apino (2017), Sugiman \& Apino (2017), Sulistyani \& Retnawati (2015) telah melaporkan bahwa model-model pembelajaran dengan pendekatan konstruktivisme menjadikan siswa aktif selama proses pembelajaran berlangsung. 
Analisis data hasil tes diperoleh dari hasil pengerjaan tes yang diberikan pada pertemuan terakhir yang diikuti 34 peserta didik. Soal tes terdiri dari 4 soal uraian. Tes diperoleh setelah peserta didik mengerjakan selama 70 menit. Selesai tes, guru memeriksa dan menganalisis jawaban peserta didik untuk memperoleh data tentang hasil tes yang dilaksanakan pada pertemuan ketiga dianalisis untuk melihat kemampuan penalaran matematis peserta didik. Adapun data hasil tes peserta didik setelah dianalisis dan dikonversikan dapat dilihat pada Tabel 5.

Tabel 5. Kategori Kemampuan Penalaran Matematis Peserta didik

\begin{tabular}{cccc}
\hline Nilai & Frekuensi & $\%$ & Kategori \\
\hline $89 \leq \mathrm{n} \leq 100$ & 2 & 5,88 & Sangat Baik \\
$77 \leq \mathrm{n}<89$ & 5 & 14,71 & Baik \\
$65 \leq \mathrm{n}<77$ & 15 & 44,12 & Cukup \\
$0 \leq \mathrm{n}<65$ & 12 & 35,29 & Kurang \\
Rata-rata & & 67,89 & Cukup \\
\hline
\end{tabular}

Dari Tabel 5, dapat dilihat bahwa kemampuan penalaran matematis peserta didik termasuk dalam kategori cukup dengan rata-rata sebesar 67,89 . Peserta didik yang termasuk dalam kategori sangat baik sebanyak 2 peserta didik atau $5,88 \%$. Peserta didik yang termasuk dalam kategori baik sebanyak 5 peserta didik atau 14,71\%. Peserta didik yang termasuk dalam kategori cukup sebanyak 15 peserta didik dengan persentase $44,12 \%$, dan peserta didik yang termasuk dalam kategori kurang sebanyak 12 peserta didik dengan persentase sebesar 35,29\%.

Secara keseluruhan, rata-rata kemampuan penalaran matematis peserta didik perindikator sudah cukup dalam menjawab soal. Kebanyakan peserta didik berkategori cukup dan kurang dikarenakan kemampuan penalaran matematis peserta didik hanya dapat memenuhi 2 indikator saja, meskipun masih ada beberapa peserta didik yang memiliki kemampuan penalaran matematis sangat baik dan baik. Untuk lebih jelasnya berikut akan dibahas kelemahan atau kesalahan peserta didik pada umumnya untuk masing-masing indikator.

Menyajikan Pernyataan Matematika secara Tertulis

Persentase peserta didik yang mampu menyajikan pernyataan matematika secara tertulis yaitu sebesar $85,66 \%$ dengan kategori baik. Hal ini diukur berdasarkan kemampuan peserta didik menuliskan apa yang ada pada soal dalam bahasa matematika untuk mempermudah penyelesaian soal. Hampir seluruh peserta didik bisa meng- ubah kalimat sehari-hari ke dalam bahasa matematika. Tetapi ada beberapa peserta didik yang belum mampu mengubah kalimat menjadi bahasa matematika. Gambar 1 adalah contoh jawaban peserta didik.

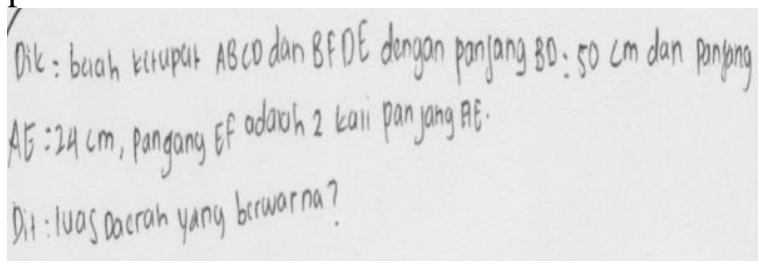

Gambar 1. Contoh Jawaban Peserta Didik yang Belum Mampu Menyajikan Masalah ke Pernyataan Matematis

Berdasarkan contoh jawaban pada Gambar 1 dapat dilihat kurangnya kemampuan peserta didik dalam menyajikan pernyataan matematis secara tertulis yaitu peserta didik menuliskan kembali soal yang telah ada. Padahal ketepatan dalam menyajikan pernyataan matematis secara tertulis merupakan kunci utama untuk mencapai ketepatan dalam menemukan hasil penyelesaian soal. Hal ini juga akan mempengaruhi skor yang diperoleh peserta didik. Seharusnya jawaban peserta didik seperti Gambar 2.

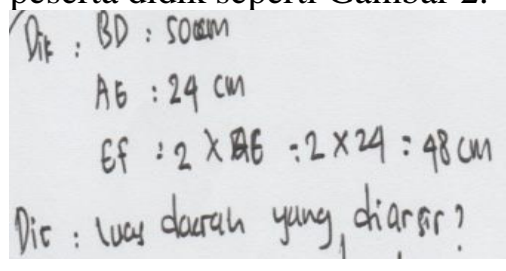

Gambar 2. Contoh Jawaban Peserta Didik yang

Telah Mampu Menyajikan Masalah ke Pernyataan Matematis

Memperkirakan Jawaban dengan Menggunakan Data yang Mendukung

Persentase peserta didik yang mampu memperkirakan jawaban dengan menggunakan data yang mendukung yaitu sebesar $89,71 \%$ dengan kategori sangat baik. Tetapi ada 4 peserta didik yang mendapat kategori kurang dan 5 peserta didik yang mendapat kategori cukup. Hal ini disebabkan karena peserta didik kurang teliti dalam menghitung dan ada beberapa peserta didik tidak menuliskan jawaban sementara dari data yang mendukung karena menganggapnya tidak penting. Gambar 3 adalah contoh jawaban yang diberikan peserta didik. 
Pythagoras, 13 (1), 2018 - 95

Trini Andira, Budi Santoso, Muhammad Yusup

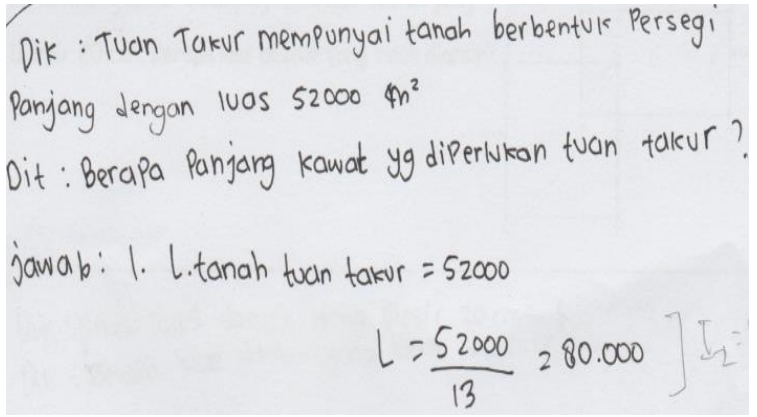

Gambar 3. Contoh Jawaban Peserta Didik yang Melakukan Kesalahan Menghitung

Seharusnya jawaban peserta didik seperti berikut.

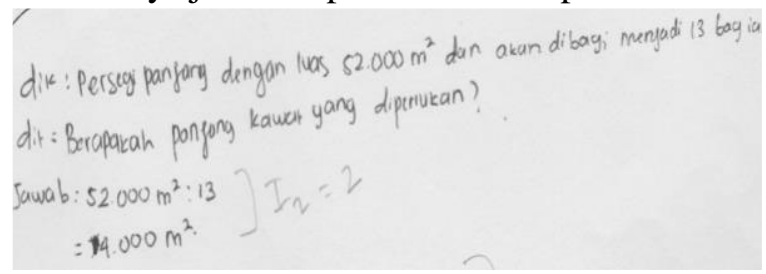

Gambar 4. Contoh Jawaban Peserta didik yang Berkategori Baik

\section{Melakukan Manipulasi Matematika}

Persentase peserta didik yang mampu melakukan manipulasi matematika yaitu sebesar $54,41 \%$ dengan kategori kurang. Walaupun dalam kategori kurang, namun masih ada beberapa peserta didik yang mempunyai kategori sangat baik. Peserta didik yang berkategori kurang ini disebabkan kesalahan awal peserta didik dalam memperkirakan jawaban dengan menggunakan data yang mendukung seperti jawaban peserta didik berikut ini.

$$
\begin{aligned}
& 170-10=160 \mathrm{~cm} \\
& \text { Dik }=17 \text { 17x10: } 170 \\
& \text { Bit yg diarsir: } 1=10 \text { jadi } 170-10=160 \mathrm{~cm}
\end{aligned}
$$

Gambar 5. Contoh Jawaban Peserta Didik yang Salah dalam Melakukan Manipulasi Matematika

Seharusnya jawaban peserta didik seperti pada Gambar 6.

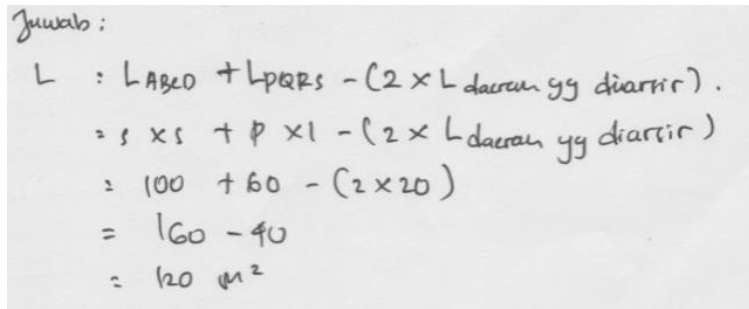

Gambar 6. Contoh Jawaban Peserta Didik Berkategori Sangat Baik
Menarik suatu Kesimpulan

Persentase peserta didik yang mampu menarik suatu kesimpulan hanya sebesar 37,50\% dengan kategori kurang. Kemampuan dalam menarik analogi dari permasalahan serupa ini merupakan yang paling rendah di antara indikator yang lain. Hal ini disebabkan karena banyaknya peserta didik yang tidak menuliskan jawaban akhir sebagai kesimpulan, karena peserta didik menganggap hal ini tidak perlu. Padahal indikator ini sangat diperlukan untuk menyelesaikan soal dengan benar. Selain itu, ada juga beberapa peserta didik yang dapat menuliskan indikator ini dengan tepat seperti contoh jawaban peserta didik pada Gambar 7.

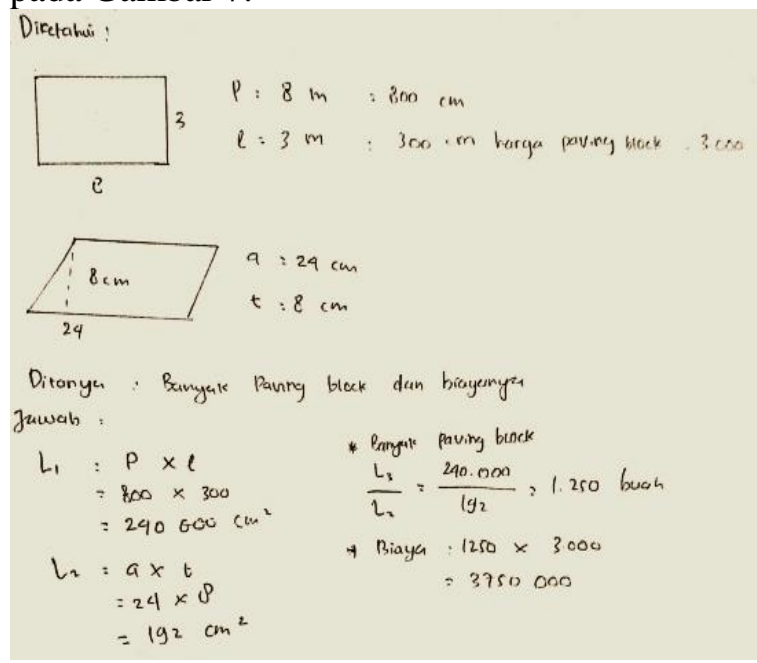

Gambar 7. Contoh Jawaban Peserta didik yang Berkategori Sangat Baik

Sebagian besar peserta didik tidak dapat menarik suatu kesimpulan, padahal peserta didik sudah mencoba menjawab pertanyaan namun kurangnya ketelitian dalam menghitung menyebabkan indikator keempat ini tidak nampak pada lembar jawaban tersebut. Berikut contoh jawaban peserta didik yang tidak membuat kesimpulan seperti pada Gambar 8 .

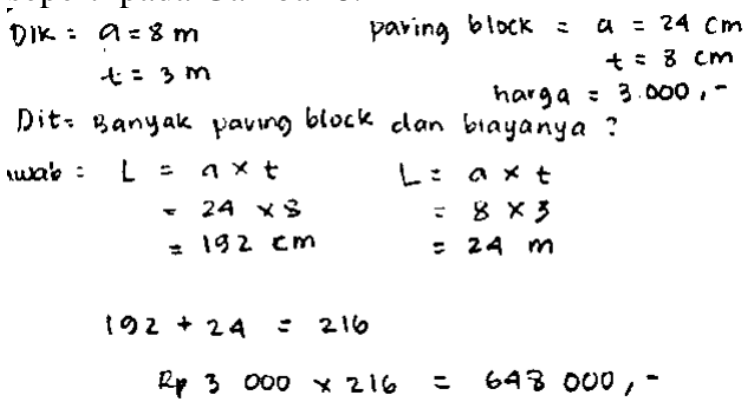

Gambar 8. Contoh Jawaban Peserta didik yang Berkategori Cukup 


\section{Pembahasan}

Berdasarkan rekapitulasi hasil tes yang dapat dilihat pada Tabel 5, secara keseluruhan kemampuan penalaran matematis peserta didik setelah diterapkan model pembelajaran Reciprocal Teaching pada materi bangun datar segiempat dikategorikan cukup dengan persentase rata-rata yaitu $67,89 \%$. Dimana terdapat 2 peserta didik atau $5,88 \%$ yang dikategorikan sangat baik, 5 peserta didik atau $17,71 \%$ dikategorikan baik, 15 peserta didik atau $44,12 \%$ dikategorikan cukup, dan 12 peserta didik atau 35,29\% dikategorikan kurang.

Berdasarkan hasil tersebut, dapat dikatakan bahwa tingkat kemampuan penalaran matematis peserta didik dengan menggunakan model Reciprocal Teaching adalah cukup. Walaupun hasil penelitian menunjukkan bahwa penerapan model pembelajaran Reciprocal Teaching pada pembelajaran dapat dijadikan alternatif pembelajaran untuk melihat kemampuan penalaran matematis peserta didik, namun masih terdapat kelemahan dalam penelitian ini yaitu, masih terdapat lebih dari $50 \%$ peserta didik yang kemampuan penalarannya dengan kategori cukup dan kurang. Hal ini sesuai dengan pendapat Sunardi (2002) bahwa peserta didik tidak dapat mencapai suatu tingkat berpikir tanpa melewati tingkat berpikir sebelumnya. Selain itu, penelitian ini hanya menggambarkan kemampuan penalaran matematis peserta didik setelah diterapkan model Reciprocal Teaching tanpa membandingkan dengan kemampuan penalaran matematis peserta didik sebelum diterapkan model Reciprocal Teaching.

Indikator yang paling besar persentase kemunculannya adalah kemampuan memperkirakan jawaban dengan menggunakan data yang mendukung dan kemampuan menyajikan pernyataan matematika secara tertulis. Kedua indikator ini dalam pembelajaran Reciprocal Teaching memang didukung oleh model pembelajaran karena dalam pembelajaran ini mendukung munculnya kedua indikator tersebut yang terdapat pada tahapan Prediction dan Summarizing.

Belum maksimalnya kemampuan penalaran matematis siswa dapat diatasi salah satunya dengan penggunaan masalah kontekstual. Wibowo (2017) mengemukakan bahwa ada beberapa langkah yang dapat menyebabkan kemampuan penalaran meningkat yaitu mengawali pembelajaran menggunakan masalah kontekstual, proses matematisasi horizontal, proses matematisasi vertikal, dan refleksi. Dari hal tersebut, dapat dipahami bahwa salah satu faktor kunci untuk meningkatkan kemampuan penalaran yaitu dengan menggunakan masalah kontekstual dalam pembelajaran. Hal ini tentunya dapat diakomodir melalui penerapan model pembelajaran Reciprocal Teaching.

\section{SIMPULAN}

Berdasarkan hasil penelitian dan pembahasan, dapat disimpulkan bahwa proses pembelajaran menggunakan model pembelajaran Reciprocal Teaching dikategorikan sangat aktif dengan rata-rata keterlaksanaan kegiatan sebesar 88,71 . Kemampuan penalaran matematis peserta didik yang dilihat dari hasil tes setelah dilakukan pembelajaran materi bangun datar segiempat dengan model pembelajaran Reciprocal Teaching sebanyak 2 pertemuan dalam penelitian ini dikategorikan cukup dengan rata-rata sebesar 67,89 .

Adapun beberapa saran dari peneliti setelah melaksanakan penelitian ini antara lain: (1) penerapan model pembelajaran Reciprocal Teaching dapat digunakan sebagai alternatif dalam pembelajaran matematika yang dapat dijadikan pilihan alternatif guru dalam proses pembelajaran, dikarenakan peserta didik dapat membangun dan menggali pengetahuan sendiri, sehingga terciptanya pembelajaran yang berpusat pada peserta didik; (2) sebelum dilaksanakan penelitian mengenai pembelajaran dengan model pembelajaran Reciprocal Teaching, alangkah lebih bainya dilaksanakan pra penelitian terlebih dahulu pada materi yang lain, sehingga ketika penelitian dimulai peserta didik sudah terbiasa dengan model pembelajaran yang digunakan; (3) Pada saat pemberian soal tes buatlah soal semenarik mungkin agar peserta didik termotivasi untuk mengerjakan soal tersebut.

\section{DAFTAR PUSTAKA}

Andalusia, R. (2011). Pengaruh pendekatan konstruktivisme pada pembelajaran matematika terhadap kemampuan penalaran matematis peserta didik Sekolah Menegah Atas. Tesis Magister tidak dipublikasikan. Palembang: Universitas Negeri Sriwijaya.

Angela, V. (2013). Pengaruh pendekatan pembelajaran reciprocal teaching terhadap kemampuan berpikir kritis peserta didik sekolah menengah pertama negeri 40 Ogan Komering Ulu. Tesis Magister tidak dipublikasikan. Palembang: Universitas Negeri Sriwijaya. 
Annisah, A., Zulkardi, Z, \& Darmawijoyo, D. (2011). Pengembangan soal-soal model PISA pada konten quantity untuk mengukur kemampuan penalaran matematis peserta didik di SMP 1 Lubuklinggau. Jurnal Pendidikan Matematika, 5(1), 1-15.

Apino, E., \& Retnawati, H. (2017, February). Developing instructional design to improve mathematical higher order thinking skills of students. In Journal of Physics: Conference Series (Vol. 812, No. 1, p. 012100). IOP Publishing.

Falach, H. N. (2016). Perbandingan keefektifan pendekatan problem solving dan problem posing dalam pembelajaran matematika pada siswa SMP. Pythagoras: Jurnal Pendidikan Matematika, 11(2), 136-148. doi: 10.21831/pg.v11i2.10635

Firdaus, M., Darma, Y., \& Haryadi, R. (2014). Kemampuan penalaran matematis dan motivasi mahapeserta didik calon guru melalui model reciprocal teaching. Jurnal Edukasi Matematika dan Sains, 2(1), 1-12.

Jailani, J., Sugiman, S., \& Apino, E. (2017). Implementing the problem-based learning in order to improve the students' HOTS and characters. Jurnal Riset Pendidikan Matematika, 4(2), 247-259. doi:10.21831/ jrpm.v4i2.17674

Kawedar, W. P. (2013). Penerapan model pembelajaran reciprocal teaching untuk meningkatkan hasil belajar peserta didik pada pokok bahasan segitiga peserta didik kelas VII-C SMP Negeri 2 Kepanjeng. Skripsi Sarjana tidak dipublikasikan. Malang: Universitas Negeri Malang.

Kemendikbud (2014). Peraturan Menteri Pendidikan dan Kebudayaan Republik Indonesia Nomor 58 Tahun 2014 tentang Kurikulum 2013 sekolah menengah pertama/ madrasah tsanawiyah.

Kemendikbud (2015). Peraturan Menteri Pendidikan dan Kebudayaan Republik Indonesia Nomor 53 Tahun 2015 tentang penilaian hasil belajar oleh pendidik dan satuan pendidikan pada pendidikan dasar dan pendidikan menengah.

NCTM (2000). Principles and standars for school mathematics. Reston, VA. Author.

Nurhayati, N. (2012). Pengembangan bahan ajar turunan fungsi melalui pendekatan konstruktivisme di sekolah menengah atas
(SMA). Tesis Magister tidak dipublikasikan. Palembang: Universitas Sriwijaya

Palinscar, A. S., \& Brown, A. L. (1986). Reciprocal teaching. Retrieved from: http://www.ncrel.org/sdrs/areas/issue/stud ents/atrisk/at6lk38.htm

Putri, R. I. (2011). Upaya meningkatkan komunikasi matematis peserta didik dalam pembelajaran matematika melalui pendekatan reciprocal teaching dengan model pembelajaran kooperatif di kelas VIII-D SMP Negeri 4 Magelang. Skripsi Sarjana tidak dipublikasikan. Yogyakarta: Universitas Negeri Yogyakarta. Retrieved from: http://eprints.uny.ac.id/2181/

Rahman, R (2014). Pengaruh penggunaan metode discovery terhadap kemampuan analogi matematika peserta didik SMK AlIkhsan Pamarican Kabupaten Ciamis Jawa Barat. Jurnal Ilmiah STKIP Siliwangi Bandung, 3(1), 33-58.

Rahman, S. A. (2015). Pengaruh model pembelajaran reciprocal teaching terhadap kemampuan berpikir kreatif pada materi lingkaran. Skripsi Sarjana tidak diterbitkan. Gorontalo: Universitas Negeri Gorontalo.

Sardiyanti, R. (2010). Penerapan model pembelajaran terbalik (reciprocal teaching) untuk meningkatkan aktivitas belajar matematika peserta didik. Skripsi Sarjana tidak diterbitkan. Jakarta: Universitas Islam Negeri Syarif Hidayatullah.

Sugiman, \& Apino, E. (2017, May). Silent method for mathematics instruction: An overview of teaching subsets. In AIP Conference Proceedings (Vol. 1848, No. 1, p. 040015). AIP Publishing.

Sulistyani, N., \& Retnawati, H. (2015). Pengembangan perangkat pembelajaran bangun ruang di SMP dengan pendekatan problem-based learning. Jurnal Riset Pendidikan Matematika, 2(2), 197-210.

Sulistyowati, Y., \& Sugiman, S. (2014). Pengembangan perangkat pembelajaran bangun ruang di SMP dengan pendekatan creative problem solving. Pythagoras: Jurnal Pendidikan Matematika, 9(2), 219232. Retrieved from http://journal.uny.ac.id/ index.php/pythagoras/article/view/9082

Suparni, S. (2016). Model pembelajaran reciprocal teaching kaitannya dengan 
Pythagoras, $13(1), 2018$ - 98

Trini Andira, Budi Santoso, Muhammad Yusup

kemampuan komunikasi matematika peserta didik. Logaritma, 4(1), 110-124.

Syah, M. (1995). Psikologi pendidikan suatu pendekatan baru. Bandung: Remaja Rosda Karya.

Wibowo, A. (2017). Pengaruh pendekatan pembelajaran matematika realistik dan saintifik terhadap prestasi belajar, kemampuan penalaran matematis dan minat belajar. Jurnal Riset Pendidikan
Matematika, 4(1), 1-10. doi: 10.21831/ jrpm.v4i1.10066

Widiastuti, W., \& Santosa, R. (2014). Pengaruh metode inkuiri terhadap ketercapaian kompetensi dasar, rasa ingin tahu, dan kemampuan penalaran matematis. Pythagoras: Jurnal Pendidikan Matematika, 9(2), 196-204. Retrieved from http://journal.uny .ac.id/index.php/pythagoras/article/view/9 080 